\title{
Auch eine ärztliche Verpflichtung
}

Jean-Jacques Fasnacht

Dr. med., Präsident PSR/IPPNW Schweiz

Das nukleare Säbelrasseln ist gleichermassen unüberhörbar wie auch überaus beunruhigend. Nordkoreanische Provokationen loten die amerikanischen und internationalen Toleranzgrenzen aus, Nordkoreas Regime und der US-Präsident üben sich in gefährlicher und unverhohlener Kriegsrhetorik, Pakistan und Indien stehen sich unverändert feindlich und $\mathrm{zu}$ einem regionalen atomaren Waffengang bestens gerüstet gegenüber, und die Reduktion der Atomwaffenbestände der letzten Jahre wird durch die teure Modernisierung des Waffenarsenals mehr als nur wettgemacht [1, 2]. Es stellt sich die bange Frage, welches Ereignis diese tödliche Maschinerie in Gang setzen könnte. Ist es menschliches Versagen bei der Handhabung dieser Waffensysteme [3] oder ist es ein politischer Konflikt, der das labile Gleichgewicht der nuklearen Abschreckung unvermittelt kippen lässt? Die katastrophalen Auswirkungen von Nuklearwaffen sind seit den Atombombenabwürfen in Hiroshima und Nagasaki 1945 bestens bekannt [4, 5]. Es sei daran erinnert, dass der hochangesehene Schweizer Arzt Dr. Marcel Junod als Mitglied des Internationalen Roten Kreuzes IKRK damals als erster ausländischer Mediziner in Japan mit den Gräueln eines Atomkrieges konfrontiert war. Das Wissen um die gesundheitlichen Risiken ionisierender Strahlung ist seither stetig gewachsen, und es ist erwiesen, dass in einem nuklearen Konflikt jegliche medizinische Hilfe heillos überfordert wäre [6].
Auch belegen wissenschaftliche Studien, dass sich selbst ein regional begrenzter Atomkrieg katastrophal auf das globale Klima auswirkt, mit daraus resultierenden landwirtschaftlichen Schäden und Hungersnöten $[7,8]$.

\section{Menschliches Versagen oder ein politischer} Konflikt kann das labile Gleichgewicht der nuklearen Abschreckung unvermittelt kippen lassen.

Angesichts dieser Evidenz des Schreckens und aufgrund unserer ethischen Verpflichtungen sind wir als Ärztinnen und Ärzte gefordert, uns dafür einzusetzen, dass Atomwaffen definitiv eliminiert werden. So haben 2015 in Moskau sämtliche in der WMA (World Medical Association) organisierten nationalen Ärztegesellschaften - unter ihnen auch die FMH - eine Erklärung zu Atomwaffen unterschrieben, welche nicht nur die Produktion, die Lagerung und den Gebrauch von Atomwaffen ächtet, sondern auch die einzelnen nationalen Ärztegesellschaften dazu aufruft, bei den jeweiligen Regierungen auf den Bann und die Eliminierung von Atomwaffen einzuwirken (s. Kasten). Zweifellos haben auch diese Bemühungen dazu beigetragen, dass sich am 7. Juli 2017 nun 122 Nationen formell auf einen UN-Vertrag zum Verbot von Atomwaffen "Treaty on the Prohibition of Nuclear Weapons» (TPNW) [9] geei-

\section{WMA STATEMENT ON NUCLEAR WEAPONS, amended by the 66th WMA General Assembly, Moscow, Russia, October 2015}

The WMA Declarations of Geneva, of Helsinki and Tokyo make clear the duties and responsibilities of the medical profession to safeguard the health of the patient and to consecrate itself to the service of humanity. The WMA considers that it has a duty to work for the elimination of nuclear weapons.

Therefore the WMA:

Condemns the development, testing, production, stockpilling, transfer, deployment, threat and use of nuclear weapons

Requests all governments to refrain from development, testing, stockpilling, transfer, deployment, threat and use of nuclear weapons and work in good faith towards the eliminations of nuclear weapons

Advises all governments that even a limited nuclear war would bring about immense human suffering and substantial death toll together with catastrophic effects on earth's ecosystem, which could subsequently decrease the world's food supply and would put a significant portion of the world's polulation at risk of famine

Requests that all National Medical Associations join the WMA supporting this Declaration, use available educational resources to educate general public and urge their respective governments to work towards the elimination of nuclear weapons

Requests all National Medical Associations to join the WMA in supporting this Declaration and urge their respective governments to work to ban and eliminate nuclear weapons. 


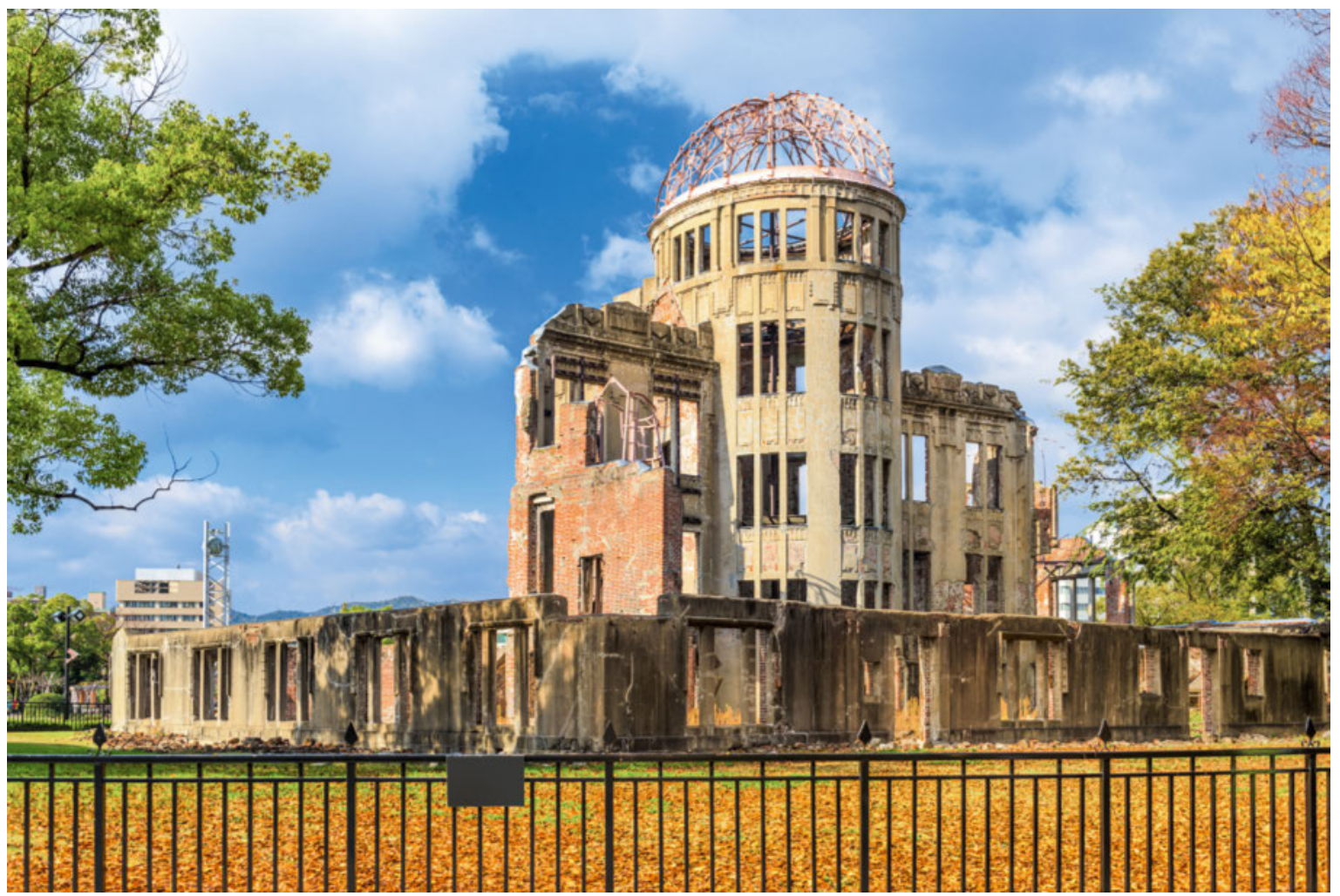

Das Friedensdenkmal von Hiroshima.

nigt haben, der am 20. September 2017 zur Unterschrift vorliegt. Unter Vorbehalten hat sich auch die Schweiz angeschlossen.

\section{Selbst ein regional begrenzter Atomkrieg wirkt sich katastrophal auf das globale Klima aus.}

Als Schweizer Medizinerinnen und Mediziner, die wir unseren ärztlichen ethischen Prinzipien verpflichtet sind, fordern wir im Einklang mit der WMA-Deklaration, dass die Schweiz diesen UN-Vertrag vollumfänglich unterstützt und signiert. Auch wenn die Atomwaffenstaaten aktuell noch nicht von ihren nuklearen Waffen ablassen wollen, ist diese weltumspannende Vereinbarung ein weiterer wichtiger Schritt zur Eliminierung dieser menschenverachtenden Massenvernichtungswaffen mit ihren inakzeptablen gesundheitlichen und humanitären Auswirkungen. Die Thematik wird ausführlich am Kongress «Human Rights, Future Generations and Crimes in the Nuclear Age» [10] zur Sprache kommen.

\section{Literatur}

1 Kristensen H, Norris R. Status of World Nuclear Forces. Federation of American Scientist, 2016, http://fas.org/issues/nuclearweapons/status-world-nuclear-forces/

2 Kristensen H. World Nuclear Weapon Modernization Programs http://fas.org/wp-content/uploads/2014/05/brief2015_NPT1a.pdf

3 Schlosser, Command and Control. Penguin Press, London, 2013.

4 World Health Organization, Effects of Nuclear War and Health and Health Service, 2nd ed. Geneva, 1987.

5 Institute of Medicine, The Medical Implications of Nuclear War, National Academy Press, Washington, 1986.

6 Helfand I, Forrow L, McCally M, Musil R. Projected US Casualties and Destruction of US Medical Services From Attacks by Russian Nuclear Forces. Medicine Global Survival 2001;7(2):68-76.

7 Robock A, Oman L, Stenchikov G, Toon O, Bardeen C, Turco R. Climatic consequences of regional nuclear conflicts. Atm Chem Phys 2007;7:2003-12.

8 Helfand I. Nuclear Famine: Two Billion People at Risk. International Physicians for the Prevention of Nuclear War, 2013, http://www.ippnw.org/nuclear-famine.html

9 United Nations General Assembly: Treaty on the Prohibition of Nuclear Weapons, 2017, http://www.undocs.org/en/a/ conf.229/2017/L.3/Rev.1

10 Kongress «Human Rights, Future Generations and Crimes in the Nuclear Age», Universität Basel, 14.-17.9.2017 (www.events-swissippnw.org), organisiert von PSR/IPPNW Schweiz und SAFNA (Schweizer Anwälte für Nukleare Abrüstung).

\section{Bildnachweis}

(c) Sean Pavone | Dreamstime.com 